\title{
On the Role of Imports in Enhancing Manufacturing Exports
}

\author{
Alessia Lo Turco and Daniela Maggioni \\ Department of Economics and Social Sciences - Universitá Politecnica delle Marche, Ancona, Italy
}

\section{INTRODUCTION}

$\mathfrak{T}$ HE expansion of global supply chains has driven an increasing weight of international transactions in intermediate goods. According to the WTO, the share of intermediate goods was around 40 per cent of non-fuel merchandise trade in 2008, with wide differences across countries. In this framework, low-income countries have played a key role. The entry of China into the WTO and the growing international openness of developing countries have brought an unprecedented opportunity in terms of cheap inputs and firm location choices for industrial countries. While large evidence exists on the effect of imports on employment, high-low skilled wage gap and productivity, ${ }^{1}$ only recently the effect of imports on the firm's export performance has started being studied.

We contribute to this new strand of literature by investigating previously unexplored drivers of the impact of importing on exporting and providing evidence on Italian manufacturing firms in the period 2000-04.

The literature has highlighted different channels through which imports may affect the firm's export status. First, the firm internationalisation is characterised by the existence of sunk costs, and some of them could be common between the import and the export activities (Roberts and Tybout, 1997; Muûls and Pisu, 2009). ${ }^{2}$ Second, importing new and more advanced goods relaxes some constraints in the production processes, thus positively affecting the firm productivity (Halpern et al., 2005). As a consequence, higher productivity firms may face the export sunk costs and/or adapt or create new goods for the foreign customers (Bas and Strauss-Khan, 2011; Kasahara and Lapham, 2012). Finally, trade liberalisation may promote the competitiveness of domestic firms through the reduction in input tariffs that, in turn, reduces the relative cost of imported inputs across all firms (Bas, 2012).

\footnotetext{
The data used in this work are from the ISTAT Annual Report, 2006. All elaborations have been conducted at the ISTAT "Laboratorio per l'Analisi dei Dati ELEmentari" under the respect of the law on the statistic secret and the personal data protection. The results and the opinions expressed in this paper are exclusive responsibility of the authors and, by no means, represent official statistics. We are grateful to Italo Colantone, Davide Castellani, Fabio Fiorillo, Alfredo Minerva and Stefano Staffolani for their useful suggestions. Also, we wish to thank participants at the LETC conference 2011 in Ljubljana, at the CAED conference 2012 in Nürnberg and at the ITSG conference 2012 in Catania for useful advice and discussions.

${ }^{1}$ To cite only a few works, the seminal papers for the US economy are Feenstra and Hanson (1996), Feenstra and Hanson (1999), Amiti and Wei (2005, 2009).

${ }^{2}$ For example, the costs of creating a foreign office concern both international activities. Also, importing from a specific country may allow the firm to gain some additional information on the business environment of that market and this may ease its penetration in such a market. In this case the linkage between import and export is supposed to be destination specific. Anyway, this channel may also generate the opposite causal nexus: from exports to imports.
} 
In short, previous empirical evidence has focused on import-export cost complementarities and on the export-enhancing effect that works through productivity gains stemming from imports. What we aim to do, instead, is to test whether, once accounted for productivity and common sunk costs, a cost-saving or a technology channel is at work. In order to dissect these effects, we split our import measure by income level of the origin countries. Although we are not able to directly investigate whether a cost-saving motivation drives imports from lowincome countries and technology search drives the ones from high-income countries, several contributions in the empirical trade literature actually hint at and adopt this split as capturing the two different motivations for imports (Jabbour, 2010; Lööf and Andersson, 2010; Smeets and Warzynski, 2010; Bas and Strauss-Khan, 2011). In addition, we will show that for Italy, the target country of our analysis, this split is rather consistent with a dichotomy between cheaper and higher quality inputs.

The firm-level evidence for Italy, so far, has shown that if learning by exporting occurs (Serti and Tomasi, 2008; Bratti and Felice, 2012), then if imports directly and positively affect the probability to export, the whole country could benefit from important feedback effects, due to the documented productivity gains originating from the firm's export activity.

Our results actually show that, once accounted for common sunk costs, firm total factor productivity, size and other firm- and sector-level characteristics, only imports from lowincome countries matter for exporting. We then interpret this finding as the increased availability of cheaper imported inputs lowering average costs, delivering higher competitiveness to the firm and enhancing the firm's export probability.

The work is structured as follows: the next section reviews the relevant literature, Section 3 presents the sample and some descriptive evidence on the import-export nexus, Section 4 introduces the empirical framework, while Section 5 discusses the results, and, finally, Section 6 concludes the work.

\section{LITERATURE REVIEW}

The penetration of foreign markets is an important strategy for a firm in the globalised world, and the drivers behind the firms' export entry have drawn the attention of economists. However, out from the literature investigating the productivity sorting of exporters, importers and two-way-traders, ${ }^{3}$ the papers that directly link the firm import and export activities are a few. Sjöholm (2003) for the period 1994-97 finds that imports of intermediates importantly affect the Indonesian manufacturing plants' probability of becoming exporters. According to the author, this finding reveals a cost-reducing effect stemming from belonging to a foreign network. In his empirical model, imports are measured by

\footnotetext{
${ }^{3}$ Due to the presence of sunk and fixed costs of exporting only more productive firms succeed to sell their goods outside the national boundaries (Roberts and Tybout, 1997; Melitz, 2003) and the existing evidence shows that exporters are in general the best performers in a sector and self-select into the export market (Bernard et al., 2007; Wagner, 2007; ISGEP, 2008). A growing strand of literature, however, is also pointing at self-selection into the import market and focusing on the two-way traders. The evidence is quite homogeneous: firms that both import and export are the best performers in a sector, compared to those that either export or import and to domestic firms (Altomonte and Bekes, 2009; Muûls and Pisu, 2009; Castellani et al., 2010; Vogel and Wagner, 2010).
} 
means of a dummy variable, and no productivity measure is directly included among the regressors. ${ }^{4}$ More recently, Muûls and Pisu (2009), for the Belgian economy, estimate a dynamic probit model for imports and exports and show that firms face sunk costs of imports that are as large as sunk costs of exports. Furthermore, once accounted for firm size and productivity, when the lagged import (export) status is included in the export (import) probability regression, the coefficient on the lagged dependent variable shrinks. The authors interpret this finding as exporting and importing having common sunk costs: a firm that is already integrated into the international markets through one of these channels may activate the other more easily. However, it is worth noting that the lagged dependent variable coefficient only modestly decreases in magnitude when the other international activity status is taken into account, and this points at other channels behind the shown positive effect, out of the common sunk costs. In other words, although cost complementarities may be important, export and import sunk costs are not really the same and they do not exhaust all the possible linkages between imports and exports. In the same line of research, a bivariate probit model of exporting and importing is estimated by Aristei et al. (2012) on a group of 27 Eastern European and Central Asian countries' firms over the period 2002-08. The positive two-way correlation between import and export runs from past imports to current exports and vice versa; however, after controlling for size, the lagged export status turns non-significant in the import equation. Also, this evidence is only partially consistent with the presence of common sunk costs: regardless of the firm size, importing may ease exporting and the firm competitiveness, while the positive effect of firms' exporting activities on sourcing of foreign inputs is mainly due to the existence of common sunk costs, correlated with firm size thresholds, and, once accounted for that, previous exporting does not make foreign sourcing more likely.

Another stream of research related to our work has focused on the import-productivityexport nexus. Apart from dealing with cost complementarities of imports and exports, the paper by Kasahara and Lapham (2012) represents a bridge between the literature on productivity effects of imported intermediates ${ }^{5}$ and the evidence on self-selection into exporting. They extend Melitz's model by incorporating imported intermediates. In their theoretical framework, imported inputs enhance productivity due to increasing returns (linked to a higher variety of imported intermediates) but, due to the high fixed cost of importing, only more productive firms can import from abroad. Thus, a firm productivity determines its participation in international markets (i.e. importing inputs and/or exporting output), and, in turn, the latter (i.e. importing inputs) has an effect on its productivity that may finally ease the entry in export markets. Trade liberalisation in intermediates increases aggregate productivity

\footnotetext{
${ }^{4}$ Nevertheless, the share of workers with more than primary education, the R\&D expenditures and the capital stock per worker are included in the analysis to account for firm specific features deeply related to the firm overall performance.

${ }^{5}$ In effect, an important part of the literature has dealt with the role of imports for productivity. Firms may take advantage from the higher technological content of imported inputs or from their complementarity with domestic materials and other inputs. Empirical works usually confirm the efficiency enhancing effect of firm access to foreign intermediates, especially when they analyse developing countries (Halpern et al., 2005; Amiti and Konings, 2007; Kasahara and Rodrigue, 2008; Morrison Paul and Yasar, 2009). For advanced economies the general finding seems to point at a rather modest or null effect of imports on productivity (Görg et al., 2008; Forlani, 2010; Vogel and Wagner, 2010; Conti et al., 2012) and when an effect occurs is more related to imports from high-income countries (Lööf and Andersson, 2010), while imports from low-income countries seem to mainly positively affect the firm profits (Jabbour, 2010).
} 
because more productive firms start importing and achieve within-plant productivity gains, which may allow them to start exporting. ${ }^{6}$ They estimate their model on plant-level Chilean data, and several counterfactual experiments suggest that there are substantial aggregate productivity and welfare gains due to trade. So, due to import and export complementarities, policies that inhibit the import of foreign intermediates can have a large adverse effect on the exports of final goods. The same causal nexus, from import to productivity and from productivity to export, is empirically investigated by Bas and Strauss-Khan (2011) on French data. The work analyses the impact of the number and diversification of imported inputs on the export scope, instead of on the export status, through the effect of imports on productivity. They test for three different mechanisms - better complementarity of inputs, transfer of technology or decreased price index - by distinguishing the origin of imports (developing vs. developed countries) and by means of an exact price index (Broda and Weinstein, 2006). They find that an increase in the number of varieties and diversification of imported inputs has a robust impact on the firm TFP. A causal nexus from import scope/diversification to export scope is also detected. The authors conclude that this effect is mainly driven by the efficiency increase induced by imports, even if this channel has not an exhaustive explanatory power.

Another channel through which imports may help the export activity is highlighted by Bas (2012) who, starting from Melitz and Ottaviano (2008), develops a trade model of heterogeneous firms to study how the access to high-quality/cheaper foreign intermediate goods affects domestic firms' export performance. In this framework, changes in the industry imported input intensity or in import duties on intermediate goods reduce relative factor costs and enhance the competitiveness of domestic firms. A reduction in trade costs acts as a homogeneous increase of productivity for the firms in a sector. Firms in these sectors, then, experience a higher probability of becoming an exporter and a larger export share of the sales. Thus, the reduction in trade costs or the increase in the intensity of cheaper foreign inputs at the sector level acts as a uniform cost-saving effect for all the firms in the sector that can consequently enjoy higher competitiveness.

Following this recent literature, we mean to test the role of imports on the export probability of Italian manufacturing firms. We claim that once accounted for productivity and export sunk costs, if a positive role exists for imports, it is mainly related to the cost-saving channel. As the works by Muûls and Pisu (2009) and Kasahara and Lapham (2012) show, even if cost complementarities in imports and exports are relevant, they only partially capture the effect of one internationalisation channel on the other. The latter work, as an example, finds that the parameter measuring the extent of cost complementarities ranges from 0.75 in the wood industry to 0.93 in food. This means that the largest part of sunk cost is specific to the type of international activity and that if imports still significantly affect exports, some other channels should be active. The above contributions suggest that the remaining channels are technology flows occurring through imports that affect the firm productivity and, in turn, the firm's export status, positive export externalities stemming from network effects and cost saving. We mean to explore the role of imports for the export probability at the firm level, investigating whether the evidence is consistent with the existence of a cost-saving or a technology channel.

\footnotetext{
${ }^{6}$ Additionally, in equilibrium, higher labour demand from new importers and exporters increases the real wage and, as a result, the least productive firms exit from the market, leading to a further increase of aggregated productivity.
} 


\section{DATA}

This section is devoted to the presentation of the data and to the discussion of some preliminary evidence on Italian manufacturing firms' export and import activities. The main data source for this work is a balanced panel of Italian limited companies covering a 5-year period from 2000 to 2004. The data set has been used by the National Statistical Institute (ISTAT) for a descriptive analysis on offshoring practices by Italian firms published in the ISTAT Annual Report for 2006, and it has been obtained through the firm-level matching between customs trade data and balance sheet data. The sample represents about 40 per cent of total manufacturing employment and output and exactly reproduces their sectoral distribution. ${ }^{7}$ The data set provides detailed information for 40,479 firms $^{8}$ on outputs and inputs, labour costs, tangible and intangible fixed assets, exports, control participation and imports of intermediates.

As in the literature (Feenstra and Hanson, 1996, 1999; OECD, 2007), researchers at Istat have defined as imports of intermediates or offshoring the firm import flows of non-energy material intermediates from all sectors and the imports of finished goods from the firm's sector. ${ }^{9}$ Also, they have split firm-level imports according to the development stage of partner countries, that is, high- and low-income economies. Unfortunately, we are not really able to observe either the detail of the overall imported products and their unit values or the detail of import origin/export destination country.

\section{a. Descriptive Evidence}

In our sample, the share of input purchasers from low-income economies has particularly grown, going from 21 per cent in 2000 to about 25 per cent of the firms in 2004. On the contrary, the share of firms importing from high-income countries has remained basically unchanged (about 31 per cent). This evolution is yet more pronounced in the subsample of exporters, which represent about 60 per cent of our sample. This hints at the recent growing role of developing economies as input suppliers for the Italian economy and at the important linkage existing between imports and exporting at the firm level. Furthermore, our data suggest the existence of a certain degree of complementarity between importing from high- and low-income countries, as a fraction of our firms purchases inputs from both sources at the same time. Nevertheless, the low incidence of this group of firms may point at possible different reasons behind the two types of imports.

\footnotetext{
${ }^{7}$ Details on the sample representativeness are not shown here for the sake of brevity but they are readily available from the authors upon request.

${ }^{8}$ The original number of firms was slightly higher, however, as standard in the literature we cleaned the sample removing firms in NACE sectors 16 and 23 and firms with some anomalous (zero or negative) or missing values for the main variables (output, materials, value added or capital). We have also excluded firms which are outliers for at least one year in the sample period. We consider as outliers those observations from the bottom and top 0.5 per cent of the distribution of some main ratio (value added on labour and capital on labour).

9 These latter flows are also part of the international fragmentation of production and it is important to take them into account: when firms decide to move some parts of their production process abroad they could decide to move the final stages too. Anyway, it is not possible to test the robustness of our results excluding these flows of goods.
} 
TABLE 1

Transition Matrix

$\begin{array}{lr}\text { Domestic firms } & 18.29 \\ \text { Importers }_{L I} & 38.48 \\ \text { Importers }_{H I} & 38.71 \\ \text { Importers }_{\text {HILI }} & 41.52\end{array}$

Note:

(i) The table only focuses on different groups of non-exporters in 2000.

Figure A1 in the Appendix shows the evolution of the average share of imports in total intermediates from high- and low-income economies in the Italian manufacturing sector ${ }^{10}$ over our sample period. From the picture, it turns out that the weight of imports from highincome economies is higher, but declining across years, while the role of inputs sourced from low-income origins steadily increases between 2000 and 2004, with their share in total inputs going from about 1.9 to 2.4 per cent. However, the overall importance of the latter group of imports could be understated, as their lower share should also reflect the lower unit price of inputs sourced from low-cost locations. More importantly, the switch to cheaper suppliers within the group of developing countries may turn into an observed mild growth of their weight as import sources. In Figure A2 we turn to our firm-level database and show the firm import shares in total intermediate inputs by export status. On average, exporters rely on imported inputs more intensively than nonexporters. Concerning the evolution of imports from developed economies, both exporters and nonexporters display the same pattern observed at the sector level. On the contrary, the import share from developing countries evolves quite differently in the two firm groupings, with exporters likely driving the sector-level evidence.

This descriptive analysis calls for a more rigorous investigation of the linkages between export and import activity. Especially, it suggests paying particular attention to the increasing role of import flows from developing countries that may have changed the competitive and economic environment where firms operate. As a matter of fact, the time span of our analysis is an interesting one: the entry of China in the WTO in December 2001, the growth in the number of developing members in the organisation and the inclusion of cheap labour cost countries in the EU starting from 1995 have boosted an unprecedented integration in the intermediate good market.

A transition matrix in the export status from 2000 to 2004 delivers us some hints about the relevance of importing for the firm's access to the foreign market. We focus on firms that are not exporting in 2000, and we define different groups of non-exporters. In particular, we identify domestic firms purchasing their inputs only in the national market, and firms sourcing intermediates from low-income, high-income countries and from both groups. The main message we get from Table 1 is that firms with previous experience in foreign markets for the input procurement are more likely to sell their goods abroad in following years. Thus, this previous experience may in some ways ease the firm's export activity.

To shed further light on the correlation between the firm entry in foreign markets and the availability of cheaper and high-tech foreign inputs, we focus on a sample of export starters.

10 Data are from the ISTAT input-output tables and the WITS-COMTRADE database. 
TABLE 2

Export Starters vs. Never Exporters

\begin{tabular}{lllr}
\hline & Starters & Never & t-test \\
\hline imp $_{\text {II }^{t-1}}$ & 0.066 & 0.021 & -13.252 \\
imp $_{H I t-1}$ & 0.106 & 0.042 & -13.541 \\
impshare $_{\text {LI } t-1}$ & 0.007 & 0.002 & -6.207 \\
impshare $_{H I}{ }^{-1}$ & 0.018 & 0.010 & -5.151 \\
imp $_{\text {LI } t-2}$ & 0.061 & 0.020 & -11.835 \\
imp $_{H I} t-2$ & 0.106 & 0.042 & -13.236 \\
impshare $_{\text {LI } t-2}$ & 0.007 & 0.002 & -6.129 \\
impshare $_{H I}{ }^{-2}$ & 0.018 & 0.010 & -5.041 \\
\hline
\end{tabular}

Note:

(i) $i m p_{L I}$ and $i m p_{H I}$ are dummies for the import activity from low-income and high-income countries. impshare $_{L I}$ and impshare $_{H I}$ are import share from the two groups of countries. $(t-1)$ and $(t-2)$ refers to one year and two years before the export entry.

We define export starters as those firms in our sample that start to export in $t$ and have not exported in the previous three years. According to our panel time span, the adoption of this definition of export starters leaves us with two waves of starters: the 2004 wave includes 1,026 firms and the 2005 includes 973 firms, for a total of 1,999 export starters. Table 2 shows the difference in the import status (and shares) between export starters and never exporters one year and two years before the entry in foreign markets. The $t$-tests reveal that in the pre-entry years, export starters are on average more likely than never exporting firms to be importers, and they also have a larger share of imports among their intermediate inputs. Even if a positive gap is displayed for purchases from both groups of countries, a larger relative difference between starters and never exporters is recorded for imports from developing countries.

The above evidence proves that, despite the larger weight of high-income origins in the Italian firms' import activity, imports from low-income countries gain importance in our sample period. In particular, future exporters present higher differences in terms of their involvement with cheap labour countries. As a consequence, we expect the existence of a causal nexus between the import activity and the export activity and, according to the descriptive analysis, the intensification of imports from developing economies seems to play an important role in the firms' internationalisation process.

However, before moving to the estimate of an empirical model to dissect the role of imports on the manufacturing firm's export probability, we mean to assess to what extent different import origins may hide different reasons for imports. The positive relationship existing between the income level of the import source and the quality and technology of the shipped products is widely supported by the existing evidence (Hallak, 2006). However, making use of the import data retrieved from the WITS-COMTRADE online database, we mean to clarify whether it is consistent to assume cost saving for imports from low-income countries and technology/better quality search for imports sourced in high-income economies. Making use of HS96 6-digit Italian imports from the two groups of high- and low-income countries, ${ }^{11}$ so as defined in the WITS database, we have first assessed the relative importance of high- and low-income partners for Italy. Table 3 summarises the information on the weight of high- and

11 The high-income group only includes OECD high-income economies, thus excluding high-income countries exporting oil. 
TABLE 3

High- and Low-income Imports into Italy - 6 Digit HS 1996 - Year 2000

\begin{tabular}{|c|c|c|c|c|c|c|c|}
\hline \multirow[t]{3}{*}{ Product Category } & \multirow[t]{3}{*}{ Codes } & \multicolumn{6}{|c|}{ Import Share from } \\
\hline & & \multicolumn{3}{|c|}{ High Income } & \multicolumn{3}{|c|}{ Low Income } \\
\hline & & Codes & Mean & p50 & Codes & Mean & $p 50$ \\
\hline 01-05 Animal and Animal Products & 199 & 199 & 0.85 & 1.00 & 114 & 0.22 & 0.09 \\
\hline 06-15 Vegetable Products & 315 & 315 & 0.75 & 0.89 & 248 & 0.30 & 0.20 \\
\hline 16-24 Foodstuffs & 186 & 186 & 0.82 & 0.97 & 147 & 0.21 & 0.04 \\
\hline 25-27 Mineral Products & 138 & 138 & 0.67 & 0.79 & 105 & 0.38 & 0.29 \\
\hline 28-38 Chemicals and Allied Industries & 779 & 778 & 0.89 & 0.98 & 555 & 0.13 & 0.04 \\
\hline 39-40 Plastics/Rubbers & 198 & 198 & 0.86 & 0.96 & 178 & 0.12 & 0.02 \\
\hline 41-43 Raw Hides, Skins, Leather, and Furs & 74 & 74 & 0.55 & 0.53 & 70 & 0.42 & 0.39 \\
\hline 44-49 Wood \& Wood Products & 227 & 226 & 0.80 & 0.93 & 196 & 0.20 & 0.07 \\
\hline 50-63 Textiles & 822 & 820 & 0.61 & 0.63 & 787 & 0.37 & 0.34 \\
\hline 64-67 Footwear/Headgear & 55 & 55 & 0.43 & 0.42 & 55 & 0.53 & 0.53 \\
\hline 68-71 Stone/Glass & 195 & 195 & 0.81 & 0.93 & 168 & 0.17 & 0.06 \\
\hline 72-83 Metals & 535 & 535 & 0.83 & 0.92 & 438 & 0.17 & 0.09 \\
\hline 84-85 Machinery/Electrical & 804 & 804 & 0.88 & 0.94 & 727 & 0.09 & 0.03 \\
\hline 86-89 Transportation & 125 & 125 & 0.87 & 0.95 & 102 & 0.10 & 0.03 \\
\hline 90-97 Miscellaneous & 389 & 389 & 0.77 & 0.88 & 371 & 0.19 & 0.06 \\
\hline Total & 5,041 & 5,037 & 0.79 & 0.92 & 4,261 & 0.21 & 0.08 \\
\hline
\end{tabular}

Note:

(i) ${ }^{* * *} p<0.01$. Source: WITS-COMTRADE. Own calculations. We compute the weight of high- and low-income countries for every six digit products and we present the average and the median shares by groups of two digit HS96 products.

low-income economies at the product level for the Italian economy in 2000, the first year of our firm-level sample. First of all, Table 3 shows that there are a number of products that are imported only from one source, more often the high-income one. Second, with the exception of traditional low-income economies' export goods (e.g. textiles, leather and footwear), the average and the median share of imports from high-income countries are above 80 per cent with the overall median equal to 92 per cent and the discrepancy between the two measures hinting at a left-skewed distribution. A right-skewed distribution, consequently, emerges for the share of imports coming from high-income economies. Specularly, the share of imports from low-income economies is rather low for the vast majority of products, and for some of them, it reaches very high levels. Then, there seems to be little overlap between the two types of imports. Although rich partners are the main trading partners, there are some products in which the share of low-income countries is rather relevant. More importantly, Table 4 shows, for the year 2000, that across products, higher unit values are associated with higher shares from high-income economies and, consequently, lower shares from low-income exporters. Also, columns 3 and 4 in the Table show that taking differences in import shares and unit values at the product level between 2000 and 2004 - the first and last year of our firm-level analysis - a within product increase in the unit value is related to an increase in the share of imports coming from high-income economies, and the reverse holds true for imports from low-income economies. Then, this simple evidence is suggestive of a sort of polarisation of imports from high- and low-income economies, respectively, in high- and low-quality 
TABLE 4

Import Share from High- and Low-income Countries

\begin{tabular}{|c|c|c|c|c|}
\hline & \multicolumn{4}{|l|}{ Import Share } \\
\hline & \multicolumn{2}{|l|}{ Year 2000} & \multicolumn{2}{|l|}{$\Delta-2000 / 2004$} \\
\hline & from HI & from $L I$ & from HI & from $L I$ \\
\hline $\log U V$ & $\begin{array}{l}0.014 \\
(0.002)^{* * *}\end{array}$ & $\begin{array}{l}-0.021 \\
(0.003) * * *\end{array}$ & & \\
\hline$\Delta \log U V$ & & & $\begin{array}{l}0.052 \\
(0.008) * * *\end{array}$ & $\begin{array}{l}-0.060 \\
(0.010)^{* * *}\end{array}$ \\
\hline Constant & $\begin{array}{l}0.779 \\
(0.005)^{* * *}\end{array}$ & $\begin{array}{l}0.234 \\
(0.006) * * *\end{array}$ & $\begin{array}{l}-0.062 \\
(0.003) * * *\end{array}$ & $\begin{array}{l}0.069 \\
(0.004) * * *\end{array}$ \\
\hline Observations & 7,484 & 6,396 & 3,697 & 2,982 \\
\hline$R^{2}$ & 0.018 & 0.025 & 0.03 & 0.031 \\
\hline
\end{tabular}

Note:

(i) $* * * p<0.01$

Source: WITS-COMTRADE. Own calculations. Dependent variable share of imports from high-income countries in columns 1 and 3 and from low- income countries in columns 2 and 4. UV is the product unit value calculated as the total value imports over total quantity.

products. As a consequence, higher shares of imports from high-income economies can be associated with higher quality goods, while higher import shares from low-income countries can be associated with cheaper products.

Following these hints, the next section means to develop an empirical model to test the effects of imports in the firm's export activity.

\section{EMPIRICAL FRAMEWORK}

In the definition of our empirical framework, we express the firm production technology as a function of labour and material inputs. We assume that material inputs is a composite good made up of different varieties, namely a domestic and an imported variety. The latter one is not homogeneous as imports from high and low labour cost countries represent two different varieties. Because the decision to enter the export market follows from the comparison of expected profits and the export sunk costs, we can proceed describing the firm's technology by means of a cost function in the level of output $y$, the firm-specific total factor productivity, $\phi$, the price and quality of labour $-w$ and $q_{w}$, respectively - and the price and quality of imported and domestic materials $-p_{m}$ and $q_{m}$ and $p_{d}$ and $q_{d}$, respectively. As already mentioned, imported inputs are, in turn, of two different types: the input coming from highincome economies is supposed to be of higher quality and its price and quality can be labelled as $p_{h}$ and $q_{h}$, while the price and quality of the input coming from low-income economies are labelled as $p_{l}$ and $q_{l}$. Inputs from the two sources are different, as they supply different types of services that in turn are different from the ones supplied by the domestic input. Nevertheless, they are imperfect substitutes, and the quality of the input from the low-income sources is rather low when compared with the quality of the other imported input. As the three types of inputs are considered as different varieties of the same homogeneous material input, we can assume that the input coming from high-income countries is the latest generation of that 
type of input, while the input coming from low-income economies does not represent the highest technology in the field, but is, however, comparable with what the domestic economy can achieve by itself. In this respect, we can assume that the domestic and low-income imported input belong to the same generation of material inputs. Although one of the varieties has rather higher quality compared with the other ones, the assumption of imperfect substitutability across varieties here supports the adoption of the three types of inputs at the same time in production. In other words, we may assume $q_{d}=q_{l}$, and in particular, we may equal the domestic generation quality level to 1 so that $q_{d}=q_{l}=1$ and $q_{h}>1$ is a proxy for the higher technology level brought by the input imported from high-income economies. A similar approach in modelling imported inputs in technology is followed by Halpern et al. (2005) who express each input $i$ as assembled from the combination of a foreign and a domestic variety, where the foreign variety displays higher productivity. Regardless of the productivity differences, the firm uses both varieties in production due to their imperfect substitutability. Their theoretical framework is devoted to the foundation of an empirical model on imports and productivity in Hungary, where the largest share of imports are from high-income economies and technology flows through imports may be the relevant channel for that economy. In our framework, instead, we include imports from low-income economies too, for which it seems sensible to assume a level of productivity at most equal to the level of the domestic variety. Also, similar to Kasahara and Lapham (2012), we consider a composite intermediate input; however, different from them, we consider each input origin (domestic, high income, low income) as a unique variety to keep the notation and the reasoning as simple as possible. We are not interested in the number of input varieties, due to the lack of such information in our data, nevertheless, relaxing the assumption of a unique variety for each origin would not alter the main conclusions from our model. So the cost function can be expressed as follows:

$$
C\left(w, p_{m}, p_{d}, y\right)=\frac{y}{\phi}\left(\frac{w}{q_{w}}\right)^{\alpha}\left[\left(\frac{p_{h}}{q_{h}}\right)^{\gamma} p_{l}^{\delta} p_{d}^{1-\gamma-\delta}\right]^{1-\alpha} \text { with } 0 \leq \alpha, \gamma, \delta \leq 1 .
$$

To keep the framework as simple as possible, we have assumed a unit elasticity of substitution across imported and domestic material inputs. ${ }^{12}$ In equation $1,0 \leq \gamma, \delta \leq 1$ represent firm-specific technology parameters. ${ }^{13}$

Assuming that firms face monopolistic competition in the unique export market and that the representative consumer's utility function is a CES over a continuum of varieties (Dixit

${ }^{12}$ We are aware that the empirical evidence on the elasticity of substitution across (imported) varieties reports estimates of such elasticity being around 3 (Broda and Weinstein, 2006; Broda et al., 2006), and possibly a CES specification would be more general. Nevertheless, we are not addressing the estimation of the elasticity of substitution across varieties and, even in this case, also the CES could appear as inappropriate due to the assumption of a constant elasticity of substitution across the three types of material inputs. Then we have preferred to stick to the more tractable Cobb-Douglas form which rules out strict complementarity, as it is ruled out from the empirical evidence, and allows yet for a certain degree of substitutability across varieties.

${ }^{13}$ We can assume that $\gamma \neq 0$ and $\delta \neq 0$ imply

$$
\frac{y}{\phi}\left(\frac{w}{q_{w}}\right)^{\alpha}\left[\left(\frac{p_{h}}{q_{h}}\right)^{\gamma} p_{l}^{\delta} p_{d}^{1-\gamma-\delta}\right]^{1-\alpha}-\frac{y}{\phi} \frac{w^{\alpha}}{q_{w}} p_{d}^{(1-\alpha)}<f_{m}
$$

with $f_{m}$ representing a firm specific sunk cost of entrance into the import market. Just as for productivity, firms draw their $f_{m}$ from a distribution and realise whether they can have access to the imported inputs or not. This treatment of the import sunk cost is similar to Kasahara and Lapham (2012), however we will not go in depth in this since we do not mean to model the entrance in the import market, instead we mean to model the effect of imports on exports. 
and Stiglitz, 1977; Krugman, 1980; Melitz, 2003), we can express the price of final output as a constant mark-up over marginal cost

$$
p_{y}=\frac{\sigma}{\sigma-1} * \frac{\left(\frac{w}{q_{w}}\right)^{\alpha}\left[\left(\frac{p_{h}}{q_{h}}\right)^{\gamma} p_{l}^{\delta} p_{d}^{1-\gamma-\delta}\right]^{1-\alpha}}{\phi},
$$

with $\sigma$ expressing the elasticity of substitution across varieties of the final good. The assumption of a unique export market is imposed by our data that only contain information on the overall export status of the firm without making any distinction across destinations. Another implicit assumption in equations 1 and 2 is that trade and transport costs are absent in our model. The choice not to model them follows from the observation that both import and export tariffs do not really vary in our five-year time span. Additionally, due to the lack of detailed information on destination and origin countries, the inclusion of distance from import and export markets is superfluous, as it would be time, sector and firm invariant. Thus, we abstract from the inclusion of iceberg costs in export and imports to avoid any unnecessary complications. From the above equations, it follows that profits are calculated as follows

$$
\Pi=\left[\frac{\left(\frac{w}{q_{w}}\right)^{\alpha}\left[\left(\frac{p_{h}}{q_{h}}\right)^{\gamma} p_{l}^{\delta} p_{d}^{1-\gamma-\delta}\right]^{1-\alpha}}{(\sigma-1) \phi}\right] y .
$$

In equilibrium, we can express output of each variety in terms of its demand as

$$
y=Y\left[\frac{p_{y}}{P}\right]^{-\sigma},
$$

with $Y$ representing the aggregate good made up of the varieties consumed and $P=\left[\int_{\omega} p(\omega)^{1-\sigma} d \omega\right]^{\frac{1}{1-\sigma}}$ representing the aggregate price.

Finally, placing 4 into 3 , we get the following expression

$$
\Pi=\frac{Y P}{\sigma}\left[\frac{(\sigma-1)}{\sigma} \frac{\phi P}{\left(\frac{w}{q_{w}}\right)^{\alpha}\left(\frac{1}{q_{h}^{1-\mu}}\right)^{\gamma(1-\alpha)} p_{l}^{\delta(1-\alpha)}}\right]^{\sigma-1},
$$

where the domestic price $p_{d}$ is taken as the numeraire and, following Halpern et al. (2005), we further assume that the relative price of the high-income country variety only imperfectly reflects the higher quality so that $\frac{p_{h}}{p_{d}}=q_{h}^{\mu}$ with $\mu<1$.

Now, the only fixed cost of production is represented by an entry sunk cost in the export market, $F_{\text {exp }}$. A firm will enter the foreign market if the expected profits are higher than this sunk entry cost. Ruling out uncertainty about future profits and defining $r$ the interest rate

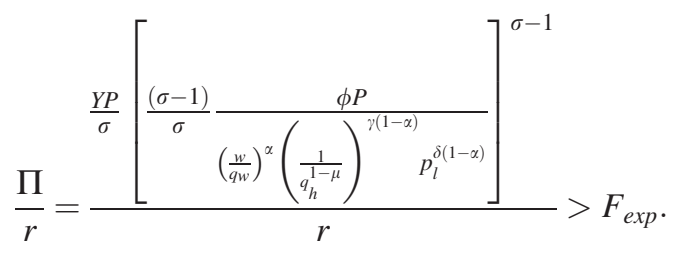

We index sectors with $j$ and define the export sunk cost as made up of a sector-specific $\delta_{j}$ component and a sector-firm idiosyncratic shock, $\rho_{i j t}$

$$
F_{\text {exp }}=e^{\delta_{j}+\rho_{i j t}} .
$$


Substituting 7 into 6 , taking the variables in logarithm and assuming that $\rho_{i j t}$ is normally distributed, we get an empirical model for the probability to export:

$$
\begin{aligned}
\operatorname{Pr}\left(\operatorname{Exp}_{i j t}=1\right)= & \operatorname{Pr}\left(\beta_{0}+\beta_{1} \ln \phi+\beta_{2} \ln _{h i t}-\beta_{3} \ln p_{l i t}-\beta_{4} \ln w_{i t}\right. \\
& \left.+\beta_{5} \ln q_{w i t}-\beta_{4} \ln r-\delta_{j}>\rho_{i j t}\right) .
\end{aligned}
$$

This simple empirical framework predicts that, ceteris paribus, a reduction in the price of inputs sourced from low-income economies and an increase in the quality of imports coming from high-income suppliers (that proxies for the relative price of inputs from developed countries with respect to domestic variety) increase the probability to export. To this purpose, we include in our empirical model the share of imports from low- and high-income countries over total intermediate inputs to proxy for the firm search of higher quality and cost saving. If, as documented above, the share of imports from low-income economies increases as import prices from these sources decline and such an increase in the import share fosters the exports activity, then we can interpret this finding as cost saving favouring exporting. ${ }^{14}$ Furthermore, if higher product quality is related to an increase in the share of imports from high-income economies, we can interpret a positive effect stemming from the increase in the share of imports from these origins as higher quality of imported inputs fostering exports. The remaining variables that we include in our probit model are the logarithm of the firm total factor productivity and the logarithm of the firm-level average wage. Our data does not provide any information on the skill level of labour inputs and, as a consequence, as far as higher labour productivity is reflected in a higher average wage, the latter, in this setting, could capture either higher labour costs or higher average quality of the labour force employed. In other words, we are uncertain about the sign of this coefficient, which often turns positive in firm-level studies (Bernard and Jensen, 2004). Although firms face different interest rates in financial markets according to their location, size and economic activity, we do not have the availability of such a detailed information and so we are compelled to consider the interest rate as constant across all of the firms in the empirical specification. As the Italian credit market is mainly geographically segmented, a location dummy could be informative here, but unfortunately, our data set does not include this information. Even if the model does not include the firm size among the export determinants, we have chosen to include the logarithm of the number of employees among our right-hand side variables as standard in the literature (Bernard and Jensen, 1999, 2004). This variable could also account for the financial constraints faced by the firm that cannot be controlled for with other indicators ${ }^{15}$. We have also included a full set of two-digit sectors and time dummies to account for sector time invariant export costs and common time shocks that may affect the overall export probability of manufacturing firms. Unfortunately, we are not able to control for the foreign ownership of the firm in this sample. We also lack any information on the firm foreign investments abroad. The inclusion of inward and outward FDI dummies would be desirable in such an empirical setting, due to the large intrafirm share of trade that is generally operated by multinationals. To assess whether the omission of such controls may result in a serious misspecification of our empirical model, we checked it using complementary information from the EFIGE database on comparable

\footnotetext{
${ }^{14}$ See Feenstra (2004, p. 119).

15 Usually a strict linkage between the financial constraints and the firm size is found in the literature (Beck et al., 2005, 2008).
} 
firm-level data on manufacturing firms from seven European countries. ${ }^{16}$ According to this survey, foreign-owned firms (firms with 10 per cent or more of foreign-owned capital) represent about 5 per cent of the total manufacturing firms. At the same time, only 2.5 per cent of the firms declare an interest to invest abroad. In addition, only 7 per cent of the exporters and 9 per cent of importers are foreign-owned, and only 4 per cent of exporters and 5 per cent of importers are foreign investors. These figures confirm that the multinational activity is not very common within the Italian manufacturing sectors and that the majority of exporters are not part of a multinational group. Thus, we are confident that our results are not considerably affected by the lack of this control.

\section{RESULTS}

To identify the effect of the firm imports on its export probability, we need to account for a number of issues related to the potential endogeneity of our main regressors. Our empirical strategy is twofold. We first focus on a sample of export starters and never exporters in a pooled probit model of the export probability to attenuate the possibility of reverse causality. ${ }^{17}$ Second, we relax the assumption of common sunk costs as sector specific (as from equation 7), and we model the persistence in the decision to export. Accounting for sunk costs in exports by means of the past export experience allows us to better identify the role of imports. Any positive role of imports in the probit for the export starters may, indeed, originate from the sunk cost complementarities in export and imports highlighted by Muûls and Pisu (2009), which may not be properly controlled for by sector dummies. We then estimate a linear probability model (LPM) over the whole sample of manufacturing firms - including firms exiting the export market, always exporters and export switchers - by means of system generalised methods of moments (GMM). Such estimator also allows us to address the causality issue by instrumenting our variables of interest. A final issue concerns the selection of more productive firms into importing: if importers are ex ante more productive, they could end up exporting just because of their higher efficiency and not because of their import activity. The lack of any control for such selection process would lead us to overstate the role of importing in both the probit model and the LPM. To account for this and for any other import effect related to the firm efficiency level, we include the firm-level TFP among other firm controls, as specified in equation 8.

Table A1 shows the descriptive statistics for the variables used in our model, while Table A2 shows their pairwise correlations. In these tables and in the following ones, impshare $_{L I}$ and impshare $_{H I}$ stand for the share of imports coming, respectively, from low- and high-income countries, $T F P_{\text {ind }}$ is the total factor productivity index, ${ }^{18} l$ is the logarithm of labour and captures the firm size and $w$ is the firm average wage. Finally, the results in each of the tables in the text show the baseline specification in column 1, the specification with all regressors lagged one year

\footnotetext{
16 The European Firms in a Global Economy: internal policies for external competitiveness (EFIGE) project examines the pattern of internationalisation of European firms. The project has developed and gathered harmonised statistical information at the firm level for seven EU countries. The collected database is representative of the country population of firms with more then 10 employees. The focus is especially on the firm international activity. More information on the project and the firm-level survey and database can be found at http://www.efige.org.

17 For this purpose, we also include the second lag of all regressors.

18 TFP has been computed using the multilateral index suggested by (Good et al., 1996). The index is centred with respect to the average firm in each two digit sector in the first year of the sample.
} 
in column 2, the inclusion of intangible and tangible assets in columns 3-6 and the substitution of the labour productivity measure for the TFP index in the last column.

\section{a. Starters}

The focus on the sample of starters - firms never exporting in the previous three years, as defined in the descriptive analysis - and never exporters allows us to disregard the role of the previous firm's export experience (that is, the lagged export status) on the probability to export at time $t$, and then we detect sunk entry costs via the inclusion of two-digit sector dummies. We estimate a model as in equation 8 on the sample of starters in their entry year in the export market and never exporters for all the years they are in our data set. Results are from pooled probit regressions, and the marginal effects are shown in Table 5. In the base specification of column 1, the right-hand side variables are entered in their value at time $(t-2)$. As column 2 in the Table shows, the results do not substantially change when we include them in their value at time $(t-1)$; however, the base specification of column 1 is our preferred, as it allows for a reduced influence of endogeneity and reverse causality problems on our results. Table 5 shows that a one percentage point increase in the imported input intensity from cheap labour cost countries, impshare $_{L I}$, is associated with an increase by 0.26 per cent in the probability to become an exporter. The involvement with suppliers from developed

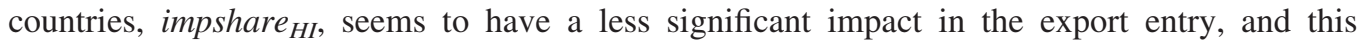
effect is not robust across the different specifications.

As standard in the literature, we confirm that larger and more efficient firms are more likely to start exporting. Also, although the finding of the positive and significant relationship between higher wages and the export probability is at odds with our empirical framework where higher unit labour costs are expected to negatively affect the firm's export probability, this is very common in the literature where higher wages are interpreted as a proxy of the firm human capital (Bernard and Jensen, 2004). As a matter of fact, the firm-level average wage may capture a number of firm-specific features that are highly correlated with this variable and that are not included in the regression. We may suppose that for Italian manufacturing firms, the higher the firm human and fixed capital stock and intensity, the higher the average wage paid by the firm. Unfortunately, we are not able to control for the firm-level skill intensity, but we have information on the firm's tangible and intangible capital stocks. When we include the logarithm of the real stocks of intangible and tangible capital, $k_{i n t}$ and $k_{\text {tan }}$, and the logarithm of their share over output, $k y_{\text {int }}$ and $k y_{\text {tan }}$ in columns 3 to 6 , both sets of indicators display positive and significant coefficients, and when the tangible capital stock is included, the wage turns to be negative. This evidence may then go in favour of our interpretation of the wage as capturing the capital/skill intensity at the firm level. The same result emerges in the last column when labour productivity substitutes for the total factor productivity index, as labour productivity is highly correlated with capital intensity. ${ }^{19}$

\section{(i) Robustness Checks}

The same insights are confirmed when, as a further robustness check, we include sectorlevel controls in Table A3. Here we have controlled for some relevant sector-level variables:

19 In our sample the correlation between the tangible capital stock and labour productivity is 0.49 while the correlation between the tangible capital stock and the total factor productivity index is much lower and is 0.19 . The two productivity measures instead show a correlation of 0.86 . 


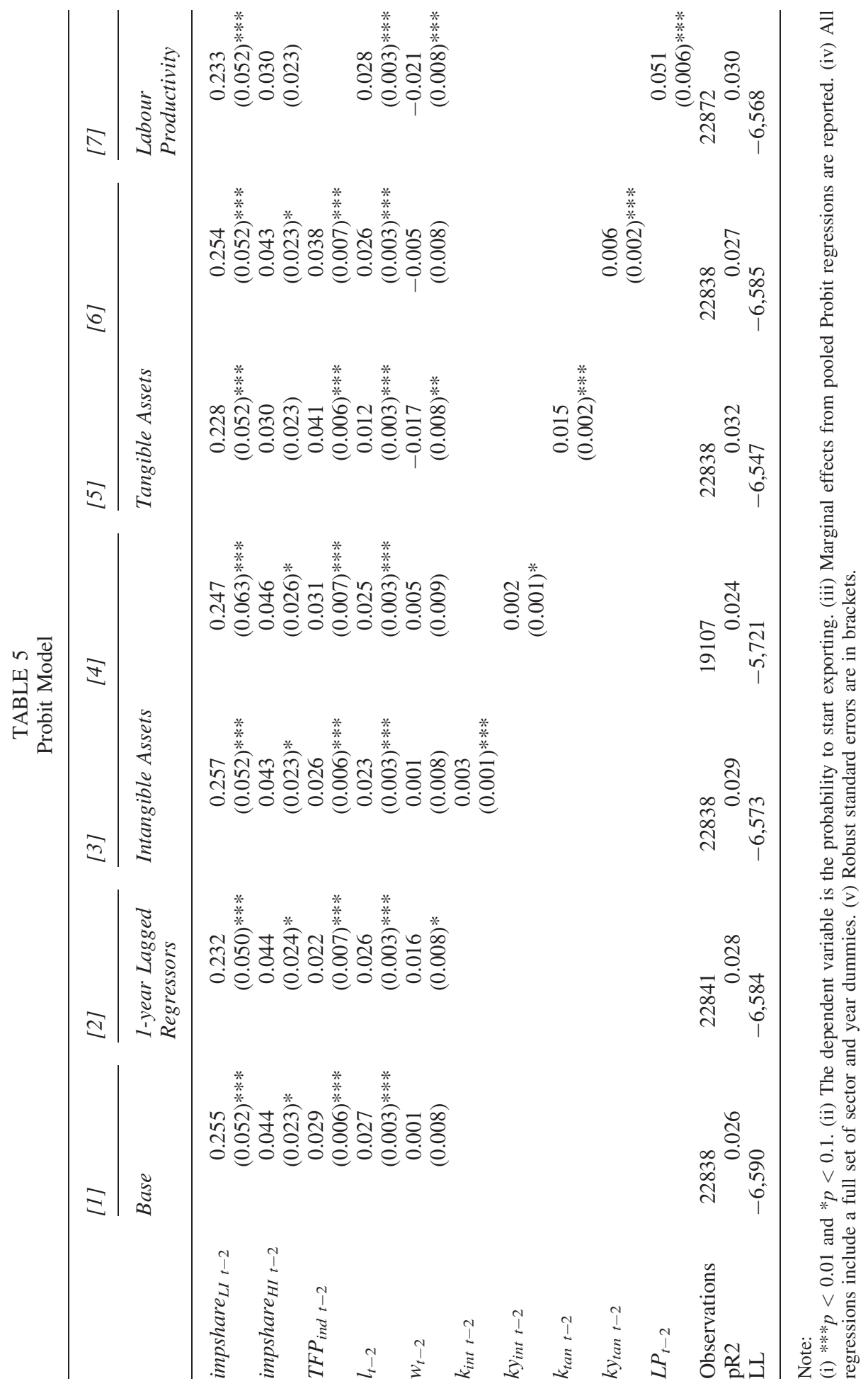


the export openness, Exp_Open, the import penetration from high and low-income countries, Imp_Pen ${ }_{H I}$ and $I m p_{-} P e n_{L I},{ }^{20}$ and the output and input tariffs from high- and low-income countries, OutputTariff ${ }_{H I}$, OutputTariff ${ }_{L I}$, InputTariff ${ }_{H I}$ and InputTariff ${ }_{L I}{ }^{21}$ All these results confirm the evidence from the baseline specification of a possible positive role of imports from low-income countries in the export status of manufacturing firms, regardless of the sector of activity. On the contrary, there seems to be no role for imports from high-income countries, especially when we also control for the firm capital intensity and the sector-level openness measures. It is worth noting that the results stay unchanged also when input tariffs are included in the specification, thus suggesting that cost saving from increased imported input intensity is not uniquely derived by trade liberalisation.

Among sector variables, the export openness seems to contribute to the firm's export success. In particular, this variable could capture, better than sector dummies, the extent of sunk costs in the export market and could then reveal the existence of spillover effects from the presence of exporters in the same sector, which have already been documented in literature (e.g. as in Serti and Tomasi 2008, for Italy). At the same time, the coefficient on the export openness may simply capture the comparative advantage of the sector. Although two-digit sector dummies may already account for this, again the three-digit export openness measure may better capture cross-sector differences within the same two-digit code and may also better capture a different time evolution pattern across sectors.

Concerning the foreign good flows in the sector, import penetration from low-income countries positively affects the probability to export, and import penetration from high-income countries displays a negative coefficient, but it is never significant. A higher share of imports from low labour cost countries may push cost saving or quality upgrading strategies to escape competition from these countries, thus enhancing the overall export probability.

Tariffs are not significant at all, and this may be linked to the fact that EU average tariffs - both with respect to high- and low-income countries - basically stayed unchanged in our sample period up to 2003 and only experienced a reduction in 2004. Then, their low time variability together with the use of two-digit-level indicators may explain why tariffs do not significantly affect the export probability in our sample.

\section{b. A Dynamic Model of the Export Determinants}

In the previous section, the role of sunk entry costs was assumed sector specific, and it was detected mainly via the inclusion of sector dummies. However, this may not be an appropriate way to identify such costs, especially if the effect of imports on the probability to export works through the common sunk costs channel as suggested by Muûls and Pisu (2009). Then, to control for the importance of sunk costs in the export activity and to ascertain that the results we have found for the import variables are not driven by common entry costs, we estimate a dynamic linear probability model on the overall sample. Once accounted

\footnotetext{
20 Export openness and import penetration ratio are obtained making use of sectoral trade data from ISTAT (COE dataset) and the Italian firms economic accounts (Conti Economici delle Imprese, ISTAT) and are defined at 3-digit NACE level. For some 3-digit sectors trade indicators are missing. The export openness measure is the ratio between the total sector exports over the sector total output, while the import penetration measure is the ratio between total sector imports over the sector absorption, that is, the summation of the sector output and imports minus exports.

${ }^{21}$ Output tariff data are from WITS and concern 2-digit NACE sectors. Input tariffs have been computed combining output tariffs and information from input-output tables (ISTAT).
} 
for past export experience, we might ascertain whether increased imported intermediate intensity still turns as a significant determinant of the export status. Furthermore, the dynamic model also permits us to estimate the role of imports including continuous exporters and switchers into the previous sample. Importing, in fact, may be relevant both to cross the border and to help the firm to preserve its position on the international markets.

The inclusion of the lagged dependent variable poses a well-known endogeneity issue due to its correlation with the individual-specific effect. GMM estimators have usually been adopted to account for this endogeneity source (Arellano and Bond, 1991; Blundell and Bond, 1998; Bond, 2002), and as far as the linear probability model is concerned, Bernard and Jensen (2004) adopt this empirical strategy on a panel of US firms, and Caldera (2010) estimates the linear probability model for export by means of GMM on a panel of Spanish firms. ${ }^{22}$ Thus, we exploit the system GMM to deal with the role of firm import activity on export status in a dynamic framework. The use of the GMM estimator also allows us to instrument our variables of interest, impshare $_{L I}$ and impshare $_{H I}$, and then to deliver causal effects to our estimates, under the validity and exogeneity of our instruments. The test for the absence of second-order autocorrelation in the differenced errors $(A R 2)$ rejects the null, thus third and fourth lags of the level of variables have been used as instruments in the differenced equation (Bond, 2002). Unfortunately, we have no way to test for third-order autocorrelation, as our sample time span prevents us from doing it; nevertheless, the failure to reject the null from the Hansen tests in each specification makes us confident of the validity of our instruments and of our estimation choice.

The results in Table 6 for the dynamic probability model in general confirm the previous finding of a positive effect of imports from low labour cost countries on the export probability, regardless of the firm activity sector. Purchases from high-income economies still remain non-significant. The confirmation of this finding makes us confident on the fact that selection into importing is not driving our results: if selection were not properly accounted for in our model, we should expect to find a strongly significant and positive impact for imports from high-income countries too. The latter effect should be even larger than the one related to imports from developing countries, as we expect productivity to more strongly drive the import activity from developed countries. ${ }^{23}$

Some differences with respect to the findings on the pooled probit on the export starters and never exporters can be detected for other firm-level variables. Wages are now significant and positive all over the specifications. To explore the drivers of this finding, which is in contrast to the previous one on the sample of export starters, we start observing that the wage positively contributes regardless of the inclusion of the capital measures. We then hypothesise that this result may follow from the inclusion of always exporters, that, in our sample, represent the largest share of exporters and that may be characterised by a higher skill intensity. To check the consistency of this interpretation, we cannot use our data due to the lack of any information on the labour force composition, and then once again we rely on complementary information from the EFIGE database from which we can retrieve information for export starters, persistent exporters and their respective skill intensity. It emerges that persistent

\footnotetext{
22 The GMM estimation of linear probability models is also used in other areas of applied economics: as an example, Stewart (2007) uses GMM to estimate a model of persistence in low pay.

23 As a check, we regressed our import share measures on lagged productivity, labour and unit wage. The results, available upon request, show that actually more productive and larger firms are more likely to import from both origins, however, the magnitude of the coefficients is larger for input purchases from developed countries.
} 
TABLE 6

Dynamic LPM - SYS GMM Estimates

\begin{tabular}{|c|c|c|c|c|c|c|c|}
\hline & [1] & [2] & [3] & [4] & [5] & [6] & \multirow{2}{*}{ 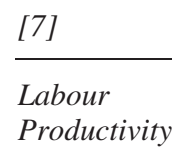 } \\
\hline & Base & \multicolumn{3}{|c|}{$\begin{array}{l}\text { 1-year Lagged Intangible Assets } \\
\text { Regressors }\end{array}$} & \multicolumn{2}{|c|}{ Tangible Assets } & \\
\hline $\exp _{t-1}$ & $\begin{array}{l}0.598 \\
(0.038) * * *\end{array}$ & $\begin{array}{l}0.590 \\
(0.038)^{* * * *}\end{array}$ & $\begin{array}{l}0.596 \\
(0.038)^{* * *}\end{array}$ & $\begin{array}{l}0.581 \\
(0.042) * * *\end{array}$ & $\begin{array}{l}0.595 \\
(0.038) * * *\end{array}$ & $\begin{array}{l}0.598 \\
(0.038) * * *\end{array}$ & $\begin{array}{l}0.594 \\
(0.038) * * *\end{array}$ \\
\hline impshare $_{L I t}$ & $\begin{array}{l}0.241 \\
(0.041)^{* * *}\end{array}$ & $\begin{array}{l}0.201 \\
(0.039) * * *\end{array}$ & $\begin{array}{l}0.239 \\
(0.041)^{* * *}\end{array}$ & $\begin{array}{l}0.247 \\
(0.043)^{* * *}\end{array}$ & $\begin{array}{l}0.232 \\
(0.041) * * *\end{array}$ & $\begin{array}{l}0.240 \\
(0.041)^{* * *}\end{array}$ & $\begin{array}{l}0.236 \\
(0.041) * * *\end{array}$ \\
\hline impshare $_{H I t}$ & $\begin{array}{r}-0.109 \\
(0.087)\end{array}$ & $\begin{array}{c}-0.0483 \\
(0.054)\end{array}$ & $\begin{array}{r}-0.115 \\
(0.087)\end{array}$ & $\begin{array}{r}-0.131 \\
(0.090)\end{array}$ & $\begin{array}{r}-0.107 \\
(0.088)\end{array}$ & $\begin{array}{r}-0.109 \\
(0.087)\end{array}$ & $\begin{array}{r}-0.112 \\
(0.087)\end{array}$ \\
\hline$T F P_{\text {ind } t}$ & $\begin{array}{l}0.0442 \\
(0.005)^{* * *}\end{array}$ & $\begin{array}{l}0.0440 \\
(0.005)^{* * *}\end{array}$ & $\begin{array}{l}0.0427 \\
(0.005)^{* * *}\end{array}$ & $\begin{array}{l}0.0536 \\
(0.006)^{* * *}\end{array}$ & $\begin{array}{l}0.0525 \\
(0.006) * * *\end{array}$ & $\begin{array}{l}0.0541 \\
(0.006)^{* * *}\end{array}$ & \\
\hline$l_{t}$ & $\begin{array}{l}0.0528 \\
(0.005)^{* * *}\end{array}$ & $\begin{array}{l}0.0508 \\
(0.005)^{* * *}\end{array}$ & $\begin{array}{l}0.0484 \\
(0.005)^{* * *}\end{array}$ & $\begin{array}{l}0.0211 \\
(0.005)^{* * *}\end{array}$ & $\begin{array}{l}0.0364 \\
(0.004)^{* * *}\end{array}$ & $\begin{array}{l}0.0252 \\
(0.005)^{* * *}\end{array}$ & $\begin{array}{l}0.0531 \\
(0.006)^{* * *}\end{array}$ \\
\hline$w_{t}$ & $\begin{array}{l}0.0202 \\
(0.005) * * *\end{array}$ & $\begin{array}{l}0.0204 \\
(0.004)^{* * *}\end{array}$ & $\begin{array}{l}0.0185 \\
(0.005)^{* * * *}\end{array}$ & $\begin{array}{l}0.0443 \\
(0.006)^{* * *}\end{array}$ & $\begin{array}{l}0.00604 \\
(0.005)\end{array}$ & $\begin{array}{l}0.0352 \\
(0.005)^{* * *}\end{array}$ & $\begin{array}{c}0.0056 \\
(0.004)\end{array}$ \\
\hline$L P_{t}$ & & & & & & & $\begin{array}{l}0.0584 \\
(0.006)^{* * *}\end{array}$ \\
\hline$k_{\text {int } t}$ & & & $\begin{array}{l}0.00357 \\
(0.000)^{* * *}\end{array}$ & & & & \\
\hline$k y_{\text {int } t}$ & & & & $\begin{array}{l}-0.00159 \\
(0.000)^{* * *}\end{array}$ & & & \\
\hline$k_{\tan t}$ & & & & & $\begin{array}{l}0.0147 \\
(0.002)^{* * *}\end{array}$ & & \\
\hline$k y_{\tan t}$ & & & & & & $\begin{array}{l}-0.00717 \\
(0.001)^{* * *}\end{array}$ & \\
\hline Const. & $\begin{array}{l}-0.101 \\
(0.046)^{* *}\end{array}$ & $\begin{array}{l}-0.0956 \\
(0.0410)^{* *}\end{array}$ & $\begin{array}{l}-0.102 \\
(0.046)^{* *}\end{array}$ & $\begin{array}{l}-0.100 \\
(0.050)^{* *}\end{array}$ & $\begin{array}{l}-0.108 \\
(0.046) * *\end{array}$ & $\begin{array}{l}-0.168 \\
(0.050)^{* * *}\end{array}$ & $\begin{array}{l}-0.574 \\
(0.073) * * *\end{array}$ \\
\hline Obse & 15,9770 & 15,9837 & 15,9770 & 14,0471 & 15,9770 & 15,9770 & 15,9880 \\
\hline Number of id & 1 40,224 & 40,236 & 40,224 & 37,703 & 4,0224 & 4,0224 & 4,0231 \\
\hline Hansen & 0.411 & 0.312 & 0.317 & 0.244 & 0.4 & 0.415 & 0.474 \\
\hline AR1 & 0 & 0 & 0 & 0 & 0 & 0 & 0 \\
\hline AR2 & 0 & 0 & 0 & 0 & 0 & 0 & 0 \\
\hline
\end{tabular}

Notes:

(i) $* * * p<0.01$ and $* * p<0.05$. (ii) All regressions include a full set of sector and year dummies. (iii) Robust standard errors are in brackets. (iv) GMM estimates are obtained using the 3rd and 4th lags of the dependent variable and regressors as instruments for the equation in differences and the 2nd lag of the differenced variables for the equation in levels. (v) The instrumented variables are the lagged dependent variable, impshare $_{L I}$ and impshare $_{H I}$. (vi) AR1 and AR2 show the $p$-value for the tests of the null hypothesis of no first and second order serial correlation in the differences of residuals. (vii) Hansen shows the $p$-value of the test of the validity of the over-identifying restrictions.

exporters are more skill intensive than switchers, in addition to have a higher skill endowment than non-exporters. Thus, in this sample, the skill gap between exporters and non-exporters is much higher than in the previous sample where only starters were included, and this may drive the positive impact we find for wages. A puzzling evidence is now shown for the capital intensity that turns to be significant and negative when we move to a dynamic framework, and we extend the analysis to all firms in the sample. A tentative explanation of this result may be related to the evidence on investments and exports being substitutes under financial constraints. While innovation and export are normally complement activities, the presence of credit constraints forces these activities to become substitutes (Gorodnichenko and Schnitzer, 
2012). Although an increase in the capital intensity may well provide enhanced efficiency and competitiveness after some years, as from the probit estimates, a contemporaneous increase in the stock of capital relative to the level of output raises the average cost, lowers the degree of competitiveness and may reduce the probability to export in the same year, if firms are financially constrained. This result, however, would deserve further investigations.

Finally, the dynamic framework allows us to investigate the role of the previous firm's export experience on its future foreign involvement. The regressions confirm the existence of important sunk export costs: the probability of exporting in $t$ is 60 per cent higher for previous exporters in $(t-1)$ than for non-exporters. This coefficient is within the range of FDGMM autoregressive parameter estimates found by Caldera (2010), while it is slightly smaller than the one found by Bernard and Jensen (2004) on the linear probability model with no plant effects and higher than the 0.39 they find with GMM difference, which traditionally bears lower coefficient estimates of the autoregressive parameter than the system GMM. Nevertheless, when they move to a random effect probit with initial condition,probability of exporting of the estimated coefficient is 0.61 , which is mimicked by our result.

Concerning the magnitude of our main results, we find that, in our sample, an increase of one percentage point in the firm import share from low-income countries increases its probability of exporting by 0.24 per cent, according to our baseline specification. Even if this effect may seem to be small, firms that heavily take advantage in their production processes of cheaper inputs sourced in developing countries may gather important benefits in terms of higher probability of exporting. As a matter of fact, firms offshoring to low labour cost countries have an average import share from these economies of about 10 per cent, and then moving from nonimporting to be an average importer from low cost countries increases the probability to export by 2.4 per cent.

\section{(i) Robustness Checks}

To test the robustness of the evidence emerging from the LPM we have run two sets of checks. First, we have assessed the GMM estimator reliability and second, as for the probit estimates above, we have added further sectoral indicators to the baseline specification. Whereas the first column of Table A4 reproduces the baseline results, in columns 2 and 3, we follow the suggestions by Roodman (2009) and display the GMM estimations with a reduced number of instruments, exploiting alternatively the third or the fourth lags of the regressors in the differenced equation and the second and the third lag of the differences in the level one. Columns 4 and 5, instead, test the inclusion of further exogenous instruments. ${ }^{24}$ In line with Bugamelli et al. (2010) and Federico (2012), we made use of the sectoral intermediate import penetration in the German economy split by origin to capture the common pattern in the German and Italian intermediate import inflows related to the process of international integration of source countries, which is uncorrelated with Italian supply and demand ${ }^{25}$ shocks. Second, as suggested by Auer and Fischer (2010), we interacted the low-wage industrial production with a sectoral indicator of labour intensity and the advanced economies' industrial production with sectoral skill intensity to

\footnotetext{
24 The data sources for these variables are the WITS-COMTRADE database, Eurostat input-output tables, the World Bank Development Indicators and the ISTAT Firm Economic Accounts.

25 Although Italy is an important source of imports of final goods for the German economy in the few Made in Italy sectors (Textiles, Clothing and Footwear), the average and the median weight of Italian imports in German intermediate imports across two digit NACE sectors is $<6$ per cent in our sample period. For this reason it is rather unlikely that our instrument - which excludes the final demand component of German imports - directly affects the export status of our firms.
} 
instrument import flows from developing and developed countries, respectively. These instruments are aimed at catching the evolution of trade stemming from exporters' relative factor endowments. Table A4 shows that our results stay unchanged and the Hansen test on the subset of instruments from level equation together with the difference-in-Hansen test confirm that the additional instruments are both valid and informative (Bond, 2002). Finally, a concern in the use of system GMM is related to the potential weakness of the GMM-style instruments that could affect the equation in levels too (Bun and Windmeijer, 2010). To check for this, we have run two-stage least squares estimations for the models in differences and in levels as in Clemens and Bazzi (2012), and we have also performed such estimator for the system including both equations. The first-stage statistics on the baseline GMM-style instruments are satisfactory, and, as expected, the system model corrects for the weak identification affecting the difference one. As far as the sector-level instruments are concerned, the first-stage statistics reveal that they contribute to identify imports from low-income economies, even if they slightly weaken the identification of imports from high-income economies. This delivers slightly worse first-stage $F$ statistics compared with our baseline estimation. However, our main insights are unchanged. Results are available from the authors upon request.

Finally, the inclusion of further sector-level variables in Table A5 supports the evidence above. Again, export openness is positive and significant. Tariffs mainly remain non-significant, while import penetration has a significant and positive impact, especially for goods coming from developing countries.

We have also tested for the existence of heterogeneity in the results according to the innovation pattern of the sector. Then, we have split the sample according to the Pavitt's taxonomy (Pavitt, 1984) in firms belonging to traditional and non-traditional (high-tech, scale and specialised suppliers) sectors, and the results do no reveal any meaningful difference. This shows that the impact of imports from low-income countries on exports does not seem to be related to some sector characteristics, but, contrariwise, seems to come from firm strategies. ${ }^{26}$

Summing up, our findings both from the probit and linear dynamic probability model confirm that only imports from low-income countries positively affect the export probability of manufacturing firms. This evidence recalls the finding by Jabbour (2010) on imports of intermediates from low-income countries, fostering profitability of French manufacturing firms. ${ }^{27}$

\section{CONCLUSIONS}

Within the recent strand of empirical literature on the relationship between exports and imports, we provide evidence on the role of imports in enhancing the export probability of manufacturing firms. We confirm that exporting and importing are two importantly interrelated strategies, and, when accounting for productivity and export sunk costs, we find that only imports from cheap labour countries positively and significantly affect the export probability of Italian manufacturing firms. We interpret this finding as the working of the cost-saving channel, opposed to the technology channel, usually identified in the literature with imports from high-

\footnotetext{
26 This set of estimates is not shown for brevity but it is readily available from the authors upon request.

27 Our evidence may seem at odds with the findings by Bas and Strauss-Khan (2011) on the export scope of French exporters being positively affected by the number of imported products from high-income countries only. However, the latter analysis is focused on the different issue of the determinants of the export scope and not on the export probability and is only run on the sample of exporters, thus, it is not able to capture the role of imports for firms to start exporting or preserving their exporter status.
} 
income countries, that in our study never turns significant. This evidence on the Italian data suggests that imports from low-income countries represent one of the key characteristics that allow firms to easily gain and preserve competitiveness in the export markets. Investigating the role of imports in manufacturing can have important implications on the understanding of the manufacturing firm's competitive strategies. This is of particular interest for the target country of our analysis, where a productivity slowdown is threatening the competitiveness of the manufacturing firms. The Italian export vocation especially relies on traditional products that have a low technological content and, consequently, face a fierce competition from emerging manufacturing economies. Competitive strategies in this setting may call for the use of cheaper inputs or/and quality upgrading of existing products. This latter process would imply an important role for inputs from developed economies, which, however, does not seem to emerge from our data. Contrarily, firms seem to have postponed/downsized their investments in favour of a cost reduction strategy to face the current combination of higher average costs and tough international competition. This appears to be valid in general, also for advanced activities, where the scope of innovation is larger. However, the recent evidence on learning by exporting (Serti and Tomasi, 2008; Bratti and Felice, 2012) together with the evidence from this paper implies that if imports, by means of cost saving, positively affect the probability to export, then this represents a good opportunity for Italy, due to productivity gains originating from the firm's export activity.

Further empirical studies on other high-income economies would be needed to investigate whether our finding on the nexus between imports and competitiveness in manufacturing is a general phenomenon or it is only confined to the case of Italy. In addition, under data availability on a much longer period than the one at our disposal, a natural extension of this research would be to investigate how actually imports of both cheaper and high-tech inputs foster persistence in the export market. Finally, in the analysis of the relationships between different internationalisation strategies, future work might be directed to test the role of foreign direct investments in enhancing both importing and exporting.

\section{APPENDIX A}

FIGURE A1

Intermediate Import Shares by Origin - Italian Manufacturing

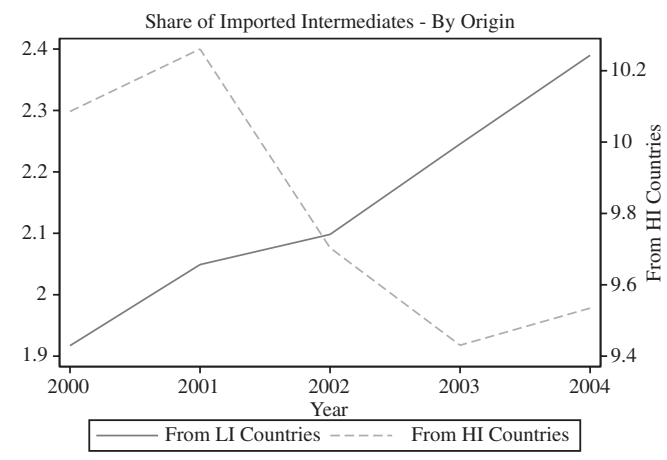

Source: Own elaborations on ISTAT input-output tables and WITS-COMTRADE. 
FIGURE A2

Firm-level Import Shares by Export Status and Import Origin
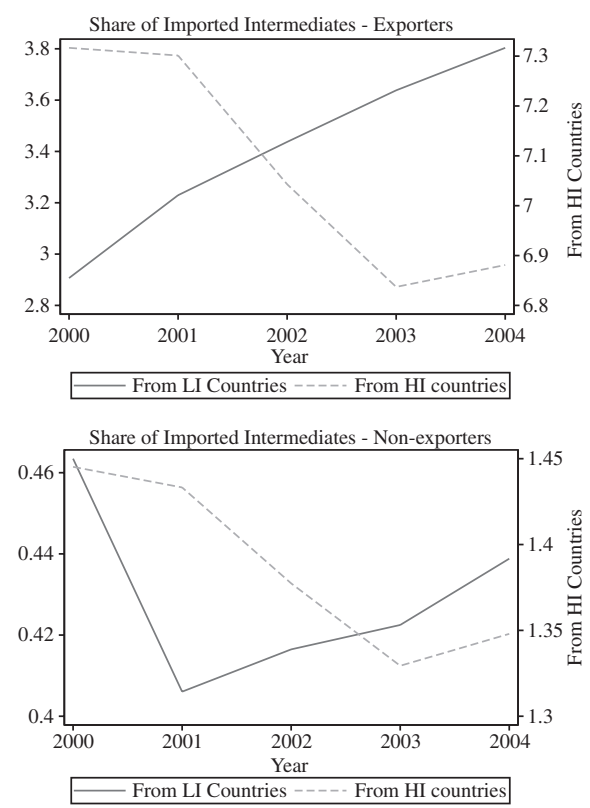

Source: Own elaborations on ISTAT data base.

TABLE A1

Descriptive Statistics

\begin{tabular}{|c|c|c|c|c|}
\hline Variable & & Mean & Std. Dev. & Observations \\
\hline \multirow[t]{3}{*}{$\exp$} & overall & 0.63 & 0.48 & $N=200964$ \\
\hline & between & & 0.44 & $n=40385$ \\
\hline & within & & 0.21 & T-bar $=4.9762$ \\
\hline \multirow[t]{3}{*}{$T F P_{\text {ind }}$} & overall & -0.06 & 0.42 & $N=202246$ \\
\hline & between & & 0.37 & $n=40472$ \\
\hline & within & & 0.20 & T-bar $=4.99718$ \\
\hline \multirow[t]{3}{*}{$l$} & overall & 2.89 & 1.06 & $N=202395$ \\
\hline & between & & 1.05 & $n=40479$ \\
\hline & within & & 0.17 & $\mathrm{~T}=5$ \\
\hline \multirow[t]{3}{*}{$w$} & overall & 10.04 & 0.38 & $N=202387$ \\
\hline & between & & 0.36 & $n=40479$ \\
\hline & within & & 0.13 & T-bar $=4.9998$ \\
\hline \multirow[t]{3}{*}{ impshare $_{L I}$} & overall & 0.02 & 0.09 & $N=201293$ \\
\hline & between & & 0.09 & $n=40406$ \\
\hline & within & & 0.03 & T-bar $=4.98176$ \\
\hline \multirow[t]{3}{*}{ impshare $_{H I}$} & overall & 0.05 & 0.13 & $N=201293$ \\
\hline & between & & 0.13 & $n=40406$ \\
\hline & within & & 0.05 & $\mathrm{~T}-\mathrm{bar}=4.98176$ \\
\hline
\end{tabular}


TABLE A2

Pairwise Correlation Coefficients

\begin{tabular}{lllllll}
\hline & TFP $_{\text {ind }}$ & $l$ & $w$ & exp & impshare $_{L I}$ & impshare $_{H I}$ \\
\hline$T F P_{\text {ind }}$ & 1 & & & & & \\
$l$ & 0.31 & 1 & & & & \\
$w$ & 0.65 & 0.5 & 1 & & & \\
exp & 0.23 & 0.35 & 0.25 & 1 & 1 & 1 \\
impshare $_{L I}$ & 0.07 & 0.12 & $0.0022 \mathrm{~ns}$ & 0.16 & 1 & \\
impshare $_{H I}$ & 0.2 & 0.27 & 0.23 & 0.21 & 0.07 & \\
\hline
\end{tabular}

Note:

(i) All significant at $1 \% . \mathrm{ns}=$ not significant.

TABLE A3

Robustness checks - Sector-Level Controls

\begin{tabular}{|c|c|c|c|c|}
\hline & [1] & [2] & [3] & [4] \\
\hline & Export Openness & Import Penetration & Output Tariffs & Input Tariffs \\
\hline impshare $_{L I} t-2$ & $\begin{array}{l}0.259 \\
(0.058) * * *\end{array}$ & $\begin{array}{l}0.256 \\
(0.058) * * *\end{array}$ & $\begin{array}{l}0.254 \\
(0.052) * * *\end{array}$ & $\begin{array}{l}0.255 \\
(0.052) * * *\end{array}$ \\
\hline impshare $_{H I} t-2$ & $\begin{array}{c}0.039 \\
(0.025)\end{array}$ & $\begin{array}{c}0.037 \\
(0.025)\end{array}$ & $\begin{array}{c}0.043 \\
(0.023) *\end{array}$ & $\begin{array}{l}0.043 \\
(0.023) *\end{array}$ \\
\hline$T F P_{\text {ind } t-2}$ & $\begin{array}{l}0.030 \\
(0.007)^{* * *}\end{array}$ & $\begin{array}{l}0.029 \\
(0.007)^{* * *}\end{array}$ & $\begin{array}{l}0.029 \\
(0.006) * * *\end{array}$ & $\begin{array}{l}0.029 \\
(0.006)^{* * *}\end{array}$ \\
\hline$l_{t-2}$ & $\begin{array}{l}0.025 \\
(0.003)^{* * *}\end{array}$ & $\begin{array}{l}0.024 \\
(0.003) * * *\end{array}$ & $\begin{array}{l}0.027 \\
(0.003)^{* * *}\end{array}$ & $\begin{array}{l}0.027 \\
(0.003)^{* * *}\end{array}$ \\
\hline$w_{t-2}$ & $\begin{array}{c}-0.001 \\
(0.009)\end{array}$ & $\begin{array}{r}-0.000 \\
(0.009)\end{array}$ & $\begin{array}{c}0.001 \\
(0.008)\end{array}$ & $\begin{array}{c}0.001 \\
(0.008)\end{array}$ \\
\hline Exp.Open $_{t-2}$ & $\begin{array}{l}0.096 \\
(0.016)^{* * *}\end{array}$ & & & \\
\hline $\operatorname{Imp}$ Pen $_{H I} t-2$ & & $\begin{array}{c}-0.015 \\
(0.022)\end{array}$ & & \\
\hline $\operatorname{Imp}$ Pen $_{L I} t-2$ & & $\begin{array}{l}0.238 \\
(0.083)^{* * *}\end{array}$ & & \\
\hline OutputTariff $_{L I} t-2$ & & & $\begin{array}{c}-0.000 \\
(0.002)\end{array}$ & \\
\hline OutputTariff $_{H I} t-2$ & & & $\begin{array}{c}-0.004 \\
(0.004)\end{array}$ & \\
\hline InputTariff $_{L I} t-2$ & & & & $\begin{array}{c}0.001 \\
(0.004)\end{array}$ \\
\hline 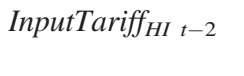 & & & & $\begin{array}{c}-0.009 \\
(0.008)\end{array}$ \\
\hline Observations & 18,864 & 18,741 & 22,838 & 22,838 \\
\hline $\mathrm{pR} 2$ & 0.027 & 0.024 & 0.026 & 0.026 \\
\hline LL & $-5,539$ & $-5,506$ & $-6,589$ & $-6,589$ \\
\hline
\end{tabular}

Notes:

(i) $* * * p<0.01$ and $* p<0.1$. (ii) The dependent variable is the probability to start exporting. (iii) Marginal effects from pooled Probit regressions are reported. (iv) All regressions include a full set of sector and year dummies. (v) Robust standard errors are in brackets. 
TABLE A4

Dynamic LPM - Robustness Checks - Estimator

\begin{tabular}{|c|c|c|c|c|c|}
\hline & \multirow{2}{*}{$\frac{[1]}{\text { Base }}$} & \multirow{2}{*}{$\frac{[2]}{\text { Lag2 }}$} & \multirow{2}{*}{$\frac{[3]}{\text { Lag3 }}$} & \multirow{2}{*}{$\begin{array}{l}{[4]} \\
\text { German } \\
\text { Intermediate }\end{array}$} & \multirow{2}{*}{$\begin{array}{l}{[5]} \\
\text { Auer and } \\
\text { Fisher (2010) }\end{array}$} \\
\hline & & & & & \\
\hline \multirow[t]{2}{*}{$\exp _{t-1}$} & 0.598 & 0.607 & 0.568 & 0.596 & 0.599 \\
\hline & $(0.038)^{* * * *}$ & $(0.050) * * *$ & $(0.119) * * *$ & $(0.038)^{* * *}$ & $(0.038)^{* * *}$ \\
\hline \multirow[t]{2}{*}{ impshare $_{L I t}$} & 0.241 & 0.247 & 0.298 & 0.243 & 0.241 \\
\hline & $(0.041) * * *$ & $(0.051)^{* * *}$ & $(0.111)^{* * *}$ & $(0.041) * * *$ & $(0.041) * * *$ \\
\hline \multirow[t]{2}{*}{ impshare $_{H I} t$} & -0.109 & -0.050 & -0.252 & -0.098 & -0.107 \\
\hline & $(0.087)$ & (0.113) & $(0.163)$ & $(0.087)$ & $(0.087)$ \\
\hline \multirow[t]{2}{*}{$T F P_{\text {ind } t}$} & 0.044 & 0.042 & 0.050 & 0.044 & 0.044 \\
\hline & $(0.005) * * *$ & $(0.006) * * *$ & $(0.013)^{* * *}$ & $(0.005) * * *$ & $(0.005) * * *$ \\
\hline \multirow[t]{2}{*}{$l_{t}$} & 0.053 & 0.050 & 0.060 & 0.053 & 0.053 \\
\hline & $(0.005)^{* * *}$ & $(0.007)^{* * *}$ & $(0.015)^{* * *}$ & $(0.005)^{* * *}$ & $(0.005)^{* * *}$ \\
\hline \multirow[t]{2}{*}{$w_{t}$} & 0.020 & 0.019 & 0.025 & 0.020 & 0.020 \\
\hline & $(0.005)^{* * *}$ & $(0.005)^{* * *}$ & $(0.009) * * *$ & $(0.005) * * *$ & $(0.005)^{* * *}$ \\
\hline \multirow{2}{*}{ Const. } & -0.101 & -0.086 & -0.143 & -0.099 & -0.101 \\
\hline & $(0.046)^{* *}$ & $(0.050)^{*}$ & $(0.067)^{* *}$ & $(0.046)^{* *}$ & $(0.046)^{* *}$ \\
\hline Obs. & 159,770 & 159,770 & 159,770 & 159,770 & 159,770 \\
\hline id & 40,224 & 40,224 & 40,224 & 40,224 & 40,224 \\
\hline Hansen $^{\mathrm{a}}$ & 0.411 & 0.265 & 0.376 & 0.541 & 0.498 \\
\hline AR1 & 0.000 & 0.000 & 0.000 & 0.000 & 0.000 \\
\hline AR2 & 0.000 & 0.000 & 0.000 & 0.000 & 0.000 \\
\hline Hansen-Lev ${ }^{\mathrm{b}}$ & 0.572 & 0.331 & & 0.680 & 0.645 \\
\hline Difference -Hansen ${ }^{c}$ & 0.265 & 0.258 & 0.541 & 0.220 & 0.290 \\
\hline
\end{tabular}

Notes:

(i) $* * * p<0.01, * * p<0.05, * p<0.1$. (ii) All regressions include a full set of sector and year dummies. (iii) Robust standard errors are in brackets. (iv) GMM estimates of columns 1, 4 and 5 are obtained using the 3rd and 4th lags of the dependent variable and regressors as instruments for the equation in differences and the 2nd lag of the differenced variables for the equation in levels. (v) German intermediate imports split by origin, and the Auer \& Fisher style instruments are included as additional exogenous instruments in column 4 and 5, respectively. (vi) In column 2 (3) the 3rd (4rd) lag only of the dependent variable, and regressors are used as instruments for the equation in differences and the 2nd (3rd) lag of the differenced variables for the equation in levels. (vii) The instrumented variables are the lagged dependent variable, impshare $_{L I}$ and impshare $_{H I}$. (viii) AR1 and AR2 show the $p$-value for the tests of the null hypothesis of no first- and second-order serial correlation in the differences of residuals. (ix) Hansen shows the $p$ value of the test of the validity of the over-identifying restrictions. (x) ${ }^{a} \mathrm{p}$-value of the Hansen test for overidentifying restrictions; ${ }^{b}$ p-value of the Hansen test for subset of instruments in level; and ${ }^{c}$ p-value of the difference-in-Hansen test. 
TABLE A5

Dynamic LPM Robustness Checks - Sector-level Controls

\begin{tabular}{|c|c|c|c|c|}
\hline & [1] & [2] & [3] & [4] \\
\hline & Export Openness & Import Penetration & Output Tariffs & Input Tariffs \\
\hline $\exp _{t-1}$ & $\begin{array}{l}0.583 \\
(0.041)^{* * *}\end{array}$ & $\begin{array}{l}0.582 \\
(0.040) * * *\end{array}$ & $\begin{array}{l}0.598 \\
(0.038)^{* * *}\end{array}$ & $\begin{array}{l}0.598 \\
(0.038) * * *\end{array}$ \\
\hline impshare $_{L I t}$ & $\begin{array}{l}0.203 \\
(0.040)^{* * *}\end{array}$ & $\begin{array}{l}0.203 \\
(0.040)^{* * *}\end{array}$ & $\begin{array}{l}0.242 \\
(0.041) * * *\end{array}$ & $\begin{array}{l}0.243 \\
(0.041)^{* * *}\end{array}$ \\
\hline impshare $_{H I t}$ & $\begin{array}{c}-0.103 \\
(0.089)\end{array}$ & $\begin{array}{r}-0.113 \\
(0.089)\end{array}$ & $\begin{array}{c}-0.11 \\
(0.087)\end{array}$ & $\begin{array}{c}-0.111 \\
(0.087)\end{array}$ \\
\hline$T F P_{\text {ind } t}$ & $\begin{array}{l}0.0449 \\
(0.005)^{* * *}\end{array}$ & $\begin{array}{l}0.0452 \\
(0.005)^{* * *}\end{array}$ & $\begin{array}{l}0.044 \\
(0.005)^{* * *}\end{array}$ & $\begin{array}{l}0.044 \\
(0.005)^{* * *}\end{array}$ \\
\hline$l_{t}$ & $\begin{array}{l}0.052 \\
(0.005)^{* * *}\end{array}$ & $\begin{array}{l}0.053 \\
(0.006) * * *\end{array}$ & $\begin{array}{l}0.053 \\
(0.005)^{* * *}\end{array}$ & $\begin{array}{l}0.053 \\
(0.005) * * *\end{array}$ \\
\hline$w_{t}$ & $\begin{array}{l}0.026 \\
(0.006) * * * *\end{array}$ & $\begin{array}{l}0.027 \\
(0.006) * * *\end{array}$ & $\begin{array}{l}0.020 \\
(0.005)^{* * *}\end{array}$ & $\begin{array}{l}0.020 \\
(0.005) * * * *\end{array}$ \\
\hline Exp.Open $_{t}$ & $\begin{array}{l}0.185 \\
(0.020)^{* * *}\end{array}$ & & & \\
\hline $\operatorname{Imp}$ Pen $_{H I t}$ & $\begin{array}{l}0.019 \\
(0.010)^{*}\end{array}$ & & & \\
\hline $\operatorname{Imp}$ Pen $_{L I t}$ & & $\begin{array}{l}0.314 \\
(0.045)^{* * *}\end{array}$ & & \\
\hline OutputTariff $_{L I t}$ & & & $\begin{array}{c}-0.001 \\
(0.001)\end{array}$ & \\
\hline OutputTariff $_{H I t}$ & & & $\begin{array}{c}-0.001 \\
(0.001)\end{array}$ & \\
\hline InputTariff $_{L I t}$ & & & & $\begin{array}{c}-0.001 \\
(0.002)\end{array}$ \\
\hline InputTariff $_{H I t}$ & & & & $\begin{array}{c}-0.002 \\
(0.001)^{*}\end{array}$ \\
\hline Constant & $\begin{array}{c}0.781 \\
(0.546)\end{array}$ & $\begin{array}{l}0.45 \\
(0.523)\end{array}$ & $\begin{array}{l}-0.088 \\
(0.047)^{*}\end{array}$ & $\begin{array}{c}-0.082 \\
(0.048)^{*}\end{array}$ \\
\hline Obs. & 143,145 & 142,068 & 159,770 & 159,770 \\
\hline $\begin{array}{l}\text { id } \\
\text { Hansen }\end{array}$ & 36,510 & 36,273 & 40,224 & 40,224 \\
\hline Hansen & 0.283 & 0.396 & 0.431 & 0.444 \\
\hline AR1 & 0.000 & 0.000 & 0.000 & 0.000 \\
\hline AR2 & 0.000 & 0.000 & 0.000 & 0.000 \\
\hline
\end{tabular}

Notes:

(i) $* * * p<0.01$ and $* p<0.1$. (ii) All regressions include a full set of sector and year dummies. (iii) Robust standard errors are in brackets. (iv) GMM estimates are obtained using the 3rd and 4th lags of the dependent variable and regressors as instruments for the equation in differences and the 2nd lag of the differenced variables for the equation in levels. (v) The instrumented variables are the lagged dependent variable, impshare $_{L I}$ and impshare $_{H I}$. (vi) AR1 and AR2 show the $p$-value for the tests of the null hypothesis of no first and second order serial correlation in the differences of residuals. (vii) Hansen shows the $p$-value of the test of the validity of the over-identifying restrictions. 


\section{REFERENCES}

Altomonte, C. and G. Bekes (2009), 'Trade Complexity and Productivity', Discussion Papers 0914, (Budapest: Institute of Economics, Hungarian Academy of Sciences).

Amiti, M. and J. Konings (2007), 'Trade Liberalization, Intermediate Inputs, and Productivity: Evidence from Indonesia'. American Economic Review, 97, 5, 1611-38.

Amiti, M. and S. Wei (2005), 'Fear of Service Outsourcing: Is It Justified?', CEPR \& CES \& MSH, 20, $42,308-47$.

Amiti, M. and S. Wei (2009), 'Service Offshoring and Productivity: Evidence from the United States', The World Economy, 32, 2, 203-20.

Arellano, M. and S. Bond (1991), 'Some Tests of Specification for Panel Data: Monte Carlo Evidence and an Application to Employment Equations'. Review of Economic Studies, 58, 2, 277-97.

Aristei, D., D. Castellani and C. Franco (2012), 'Firms' Exporting and Importing Activities: Is there a Two-way Relationship?', Review of World Economics, (doi: 10.1007/s10290-012-0137-y).

Auer, R. and A. Fischer (2010), 'The Effect of Low-Wage Import Competition on US Inflationary Pressure'. Journal of Monetary Economics, 57, 4, 491-503.

Bas, M. (2012), 'Trade, Foreign Inputs and Firms' Decisions: Theory and Evidence', Journal of Development Economics, 97, 2, 481-93.

Bas, M. and V. Strauss-Khan (2011), Does Importing more Inputs Raise Exports? Firm Level Evidence from France (Paris: CEPII).

Beck, T., A. Demirgüç-Kunt, L. Laeven and R. Levine (2008), 'Finance, Firm Size, and Growth', Journal of Money, Credit and Banking, 40, 7, 1379-405.

Beck, T., A. Demirgüç-Kunt and V. Maksimovic (2005), 'Financial and Legal Constraints to Growth: Does Firm Size Matter?', Journal of Finance, 60, 1, 137-77.

Bernard, A. and J. Jensen (1999), 'Exceptional Exporter Performance: Cause, Effect, or Both?', Journal of International Economics, 47, 1, 1-25.

Bernard, A., J. B. Jensen, S. J. Redding and P. K. Schott (2007), 'Firms in International Trade', Journal of Economic Perspectives, 21, 3, 105-30.

Bernard, B. A. and J. B. Jensen (2004), 'Why Some Firms Export.', The Review of Economics and Satistics, 86, 4, 561-69.

Blundell, R. and S. Bond (1998), 'Initial Conditions and Moment Restrictions in Dynamic Panel Data Models', Journal of Econometrics, 87, 115-43.

Bond, S. (2002), 'Dynamic Panel Data Models: A Guide to Microdata Methods and Practice', CeMMAP Working Paper, (09/02).

Bratti, M. and G. Felice (2012), 'Are Exporters More Likely to Introduce Product Innovations?', The World Economy, in press.

Broda, C., J. Greenfield and D. Weinstein (2006), 'From Groundnuts to Globalization: A Structural Estimate of Trade and Growth', Working Papers 12512, (Cambridge, MA: National Bureau of Economic Research).

Broda, C. and D. E. Weinstein (2006), 'Globalization and the Gains from Variety', The Quarterly Journal of Economics, 121, 2, 541-85.

Bugamelli, M., S. Fabiani and E. Sette (2010), 'The Pro-Competitive Effect of Imports from China: An Analysis on Firm-Level Price Data', Temi di discussione 737, (Rome: Banca d'Italia).

Bun, M. and F. Windmeijer (2010), 'The Weak Instrument Problem of the System GMM Estimator in Dynamic Panel Data Models', The Econometrics Journal, 13, 1, 95-126.

Caldera, A. (2010), 'Innovation and Exporting: Evidence from Spanish Manufacturing Firms', Review of World Economics (Weltwirtschaftliches Archiv), 146, 4, 657-89.

Castellani, D., F. Serti and C. Tomasi (2010), 'Firms in International Trade: Importers' and Exporters' Heterogeneity in Italian Manufacturing Industry', The World Economy, 33, 3, 424-57.

Clemens, M. and S. Bazzi (2012), 'Blunt Instruments: On Establishing the Causes of Economic Growth', American Economic Journal: Macroeconomics, in press.

Conti, G., A. L. Turco and D. Maggioni (2012), 'Rethinking the Import-productivity Nexus for Italian Manufacturing', Working Papers 381 (Ancona: Università Politecnica delle Marche).

Dixit, A. and J. Stiglitz (1977), 'Monopolistic Competition and Optimum Product Diversity', American Economic Review, 67, 3, 297-308. 
Federico, S. (2012), 'Industry Dynamics and Competition from Low-wage Countries: Evidence on Italy, Oxford Bulletin of Economics and Statistics, in press.

Feenstra, R. C. (2004), Advanced International Trade. Theory and Evidence (Princeton, NJ: Princeton University Press).

Feenstra, R. C. and G. H. Hanson (1996), 'Globalization, Outsourcing, and Wage Inequality', American Economic Review, American Economic Association, 86, 2, 240-45.

Feenstra, R. C. and G. H. Hanson (1999), 'The Impact Of Outsourcing And High-Technology Capital On Wages: Estimates For The United States, 1979-1990', The Quarterly Journal of Economics, 114, 3, 907-40.

Forlani, E. (2010), 'Irish Firms' Productivity and Imported Inputs', Core discussion papers, (Louvain-laNeuve: Université catholique de Louvain, Center for Operations Research and Econometrics (CORE)).

Good, D. H., M. I. Nadiri and R. C. Sickles (1996), 'Index Number and Factor Demand Approaches to the Estimation of Productivity', Working Papers 5790, (Cambridge, MA: National Bureau of Economic Research, Inc).

Gorodnichenko, Y. and M. Schnitzer (2012), 'Financial Constraints and Innovation: Why Poor Countries don't Catch Up', Journal of European Economic Association, in press.

Görg, H., A. Hanley and E. Strobl (2008), 'Productivity Effects of International Outsourcing: Evidence from Plant-level Data', Canadian Journal of Economics, 41, 2, 670-88.

Hallak, J. C. (2006), 'Product Quality and the Direction of Trade', Journal of International Economics, 68, 1, 238-65.

Halpern, L., M. Koren and A. Szeidl (2005), 'Imports and Productivity', Discussion Papers 5139 (London: CEPR).

ISGEP (2008), 'Understanding Cross-country Diffences in Exporter Premia: Comparable Evidence for 14 Countries', Review of World Economics (Weltwirtschaftliches Archiv), 144, 4, 596-635.

Jabbour, L. (2010), 'Offshoring and Firm Performance: Evidence from French Manufacturing Industry', The World Economy 33, 3, 507-24.

Kasahara, H. and B. Lapham (2012), 'Productivity and the Decision to Import and Export: Theory and Evidence', Journal of International Economics, in press.

Kasahara, H. and J. Rodrigue (2008), 'Does the Use of Imported Intermediates Increase Productivity? Plant-level Evidence', Journal of Development Economics, 87, 1, 106-18.

Krugman, P. (1980), 'Scale Economies, Product Differentiation, and the Pattern of Trade', American Economic Review, 70, 5, 950-59.

Lööf, H. and M. Andersson (2010), 'Imports, Productivity and Origin Markets: The Role of Knowledgeintensive Economies', The World Economy, 33, 3, 458-81.

Melitz, M. and G. I. P. Ottaviano (2008), 'Market Size, Trade, and Productivity', Review of Economic Studies, 75, 1, 295-316.

Melitz, M. J. (2003), 'The Impact of Trade on Intra-Industry Reallocations and Aggregate Industry Productivity', Econometrica, 71, 6, 1695-725.

Morrison Paul, C. and M. Yasar (2009), 'Outsourcing, Productivity, and Input Composition at the Plant Level', Canadian Journal of Economics, 42, 2, 422-39.

Muûls, M. and M. Pisu (2009), 'Imports and Exports at the Level of the Firm: Evidence from Belgium', The World Economy, 32, 5, 692-734.

OECD (2007), 'Offshoring and Employment: Trends and Impacts', Discussion paper, (Paris: OECD).

Pavitt, K. (1984), 'Sectoral Patterns of Technical Change: Towards a Taxonomy and a Theory', Research Policy, 13, 6, 343-73.

Roberts, M. J. and J. R. Tybout (1997), “The Decision to Export in Colombia: An Empirical Model of Entry with Sunk Costs", American Economic Review, 87, 4, 545-64.

Roodman, D. (2009), 'A Note on the Theme of Too Many Instruments', Oxford Bulletin of Economics and Statistics, 71, 1, 135-58.

Serti, F. and C. Tomasi (2008), 'Self Selection and Post-Entry effects of Exports. Evidence from Italian Manufacturing firms', Review of World Economics, 144, 4, 660-94.

Sjöholm, F. (2003), 'Which Indonesian Firms Export? The Importance of Foreign Networks', Papers in Regional Science, 82, 3, 333-50.

Smeets, V. and F. Warzynski (2010), 'Learning by Exporting, Importing or Both? Estimating Productivity with Multi-product Firms, Pricing Heterogeneity and the Role of International Trade', 
Working Papers 10-13, (Aarhus: University of Aarhus, Aarhus School of Business, Department of Economics).

Stewart, M. (2007), 'The Inter-related Dynamics of Unemployment and Low Pay'. Journal of Applied Econometrics, 22, 3, 511-31.

Vogel, A. and J. Wagner (2010), 'Higher Productivity in Importing German Manufacturing Firms: Selfselection, Learning from Importing, or Both?', Review of World Economics (Weltwirtschaftliches Archiv), 145, 4, 641-65.

Wagner, J. (2007), 'Exports and Productivity: A Survey of the Evidence from Firm-level Data', The World Economy, 30, 1, 60-82. 